\title{
PENGARUH JENIS ELEKTRODA DAN ARUS LAS PADA PENGELASAN HARDFACING BAJA JIS 3101 SS 400
}

\author{
Syaharuddin Rasyid ${ }^{1}$, Tri Agus Susanto ${ }^{1}$, Agung Setia Bela², M. Syukur Imam²
}

\begin{abstract}
Abstrak: Penelitian ini bertujuan untuk mengetahui pengaruh jenis elektroda dan arus las pada pengelasan hardfacing baja JIS 3101 SS 400. Jenis elektroda yang digunakan yaitu elektroda DIN 8555 E1-UM-350-GP, elektroda AWS Class No. A5.13 (Efe2), elektroda AWS Class No. A5.13 (Efe3) dan AWS E7018. Arus pengelasan yang digunakan terdiri dari tiga variasi yaitu 90 Amperre, 115 Amperre dan 140 Amperre. Material dasar yang digunakan yaitu baja JIS G 3101 SS 400 dengan dimensi tebal $6 \mathrm{~mm}$, panjang $50 \mathrm{~mm}$ dan lebar $25 \mathrm{~mm}$. Pada permukaan material dasar, kemudian dilakukan pengelasan Shielded Metal Arc Welding (SMAW) dengan menggunakan variasi elektroda dan variasi arus pengelasan yang telah disebutkan di atas, setelah itu didinginkan menggunakan pendingin udara. Dari hasil pengelasan dilakukan pengujian kekerasan dengan menggunakan metode Rockwell A (HRA), beban yang digunakan yaitu $588 \mathrm{~N}$, indentor yang digunakan yaitu intan $120^{\circ}$ dan waktu penekanan 5 detik. Dari hasil pengujian kekerasan tersebut diperoleh nilai kekerasan tertinggi yaitu menggunakan elektroda AWS Class No. A5.13 (EFe3) nilainya kekerasannya yaitu 70.2 - 80.93 HRA, kemudian diikuti oleh elektroda AWS Class No. A5.13 (EFe2) nilainya kekerasannya yaitu 62.25 - 69.43 HRA, kemudian elektroda DIN 8555 (E1-UM-350-GP) nilainya kekerasannya yaitu 58.90 - 62.90 HRA dan nilai kekerasan yang terrendah yaitu pengelasan dengan menggunakan elektroda AWS E7018 nilainya kekerasannya yaitu 51.69 58.99 HRA.
\end{abstract}

Kata kunci: Arus Las, Elektroda, Hardfacing, Kekerasan, SMAW.

\section{PENDAHULUAN}

Keausan komponen mesin merupakan masalah yang paling umum dihadapi dalam suatu industri. Faktor yang paling dominan terhadap keausan komponen mesin tersebut yaitu pemakaian yang terus-menerus. Penelitian mengenai masalah ini telah dilakukan selama bertahun-tahun, untuk mengurangi keausan baik dalam bentuk menggunakan bahan tahan aus baru atau dengan meningkatkan ketahanan aus bahan yang ada dengan metode hardfacing. Dalam hal ini, metode hardfacing banyak digunakan dalam suatu industri karena lebih tepat dan ekonomis dari pada menggunakan bahan tahan aus baru yang akan melibatkan biaya yang sangat tinggi dan waktu pembuatan yang sangat lama.

Pada tahun 1922, para peneliti memperkenalkan konsep hardfacing komponen mesin yang telah aus, bukan menggantikannya dengan bahan anti gesek (paduan antara high chromium dengan manganese). Hardfacing adalah metode yang umum digunakan untuk meningkatkan sifat kekerasan pada permukaan alat-alat pertanian, komponen untuk operasi pertambangan, komponen untuk operasi produksi dan lain-lain, salah satu komponen yang menggunakan metode hardfacing yaitu screw conveyor untuk aplikasi pemindahan concrete beton.

Dalam industri manufaktur khususnya industri beton pracetak, screw conveyor merupakan salah satu perlengkapan produksi, dimana screw conveyor memiliki peranan dalam menghantar material concrete beton dari hopper kedalam cetakan. Bagian terpenting dari screw conveyor yaitu daun screw yang berhubungan langsung dengan material concentrate. Pada penggunaannya, bagian daun screw bersentuhan langsung dengan material concrete beton sehingga mengalami keausan, hal ini dikarenakan pada perpindahan material concrete beton terjadi gesekan dan tekanan antara material concrete dengan daun screw.

Salah satu jenis bahan yang sering digunakan pada pembuatan daun screw conveyor adalah baja JIS 3101 SS400. Baja JIS 3101 SS400 ini memiliki komposisi kimia yaitu Carbon (C), Silikon (Si) dan Mangan (Mn) yang tidak terkontrol, sedangkan kandungan yang lainnya yaitu Phosphor (P) Max. 0.05 dan Sulphur (S) Max. 0.05\%. Adapun sifat mekanik baja JIS 3101 SS400 yaitu massa jenis

\footnotetext{
${ }^{1}$ Staf Pengajar D4 Jurusan Teknik Mesin Politeknik Negeri Ujung Pandang

${ }^{2}$ Alumni Program D4 Jurusan Teknik Mesin Politeknik Negeri Ujung Pandang
} 
27 Syaharuddin Rasyid, Tri Agus Susanto, Agung Setia Bela, M. Syukur Imam. Pengaruh Jenis Elektroda Dan Arus Las Pada Pengelasan Hardfacing Baja Jis 3101 Ss 400

$7860 \mathrm{~kg} / \mathrm{m}^{3}$, Modulus Young's 190-210 GPa, Tegangan Tarik 400-510 MPa, Tegangan Yield 205-245 MPa, Ratio Poisson's 0.26, dan Kekerasan 160 HB.

Untuk meningkatkan daya tahan gesek pada daun screw conveyor yang menggunakan bahan dasar Baja JIS 3101 SS400, salah satu metode yang dapat digunakan yaitu melapisi permukaan bahan dasarnya dengan metode hardfacing menggunakan sistem pengelasan Shielded Metal Arc Welding dan bahan pelapis yang digunakan yaitu elektroda hardfacing.

Pada proses hardfacing menggunakan sistem pengelasan Shielded Metal Arc Welding terdapat beberapa factor yang dapat mempengaruhi hasil pengelasan yaitu jenis elektroda dan arus las. Dengan demikian peneliti tertarik memilih judul "Pengaruh Jenis Elektroda Dan Arus Las Pada Pengelasan Hardfacing Baja JIS 3101 SS 400”.

\section{A. Hardfacing}

Hardfacing juga dikenal sebagai "hard surfacing" adalah aplikasi build up dari deposito paduan khusus dengan cara proses pengelasan untuk menahan abrasi (Pradeep : 2012).

Beberapa komponen mesin mempunyai masalah bukan hanya dalam soal keuletan tetapi juga dalam kelelahan yang disebabkan keausan permukaan tegangan yang bolak balik seperti pada roda gigi. Untuk mengatasi kesukaran tersebut perlu memberikan kekerasan yang lebih tinggi pada permukaan. Dengan jalan pengerasan kulit hal tersebut dapat diatasi, yaitu dengan pengarbonan, penitridan, pengerasan permukaan (hardfacing) dengan arus frekuensi tinggi atau dengan nyala api dan sebagainya (Surdia: 1999).

\section{B. Aplikasi Metode Hardfacing}

Pada dunia industri metode hardfacing telah banyak digunakan pada komponenkomponen mesin untuk oprasi produksi. Salah satu komponen mesin yang menggunakan metode hardfacing yaitu screw conveyor. Screw conveyor merupakan salah satu jenis alat pemindah bahan yang berbentuk ulir dan berfungsi untuk memindahkan material curah serta dapat pula untuk mencampurkan, memampatkan material yang dipindahkan dengan merubah tipe ulir. Bagian utamanya adalah poros yang dilengkapi dengan daun screw yang berputar dalam casing, poros tersebut diputar oleh motor yang terletak pada sisi luar casing.

\section{Kekerasan Bahan}

Ada beberapa definisi kekerasan bahan. Salah satu definisi dikemukakan oleh Dahlan (2000:51) bahwa "Kekerasan merupakan ukuran ketahanan terhadap deformasi tekan. Deformasi yang terjadi dapat berupa kombinasi prilaku elastic dan plastis". Kemudian definisi lain dikemukakan oleh Pranata (2011:2) bahwa "Kekerasan suatu bahan adalah kemampuan sebuah material untuk menerima beban tanpa mengalami deformasi plastis yaitu tahan terhadap identasi, tahan terhadap goresan, tahan terhadap aus dan tahan terhadap pengikisan (abrasi)".

Dari kedua definisi tersebut dapat disimpulkan bahwa Kekerasan (Hardness) adalah kemampuan material logam dalam menerima gaya berupa penetrasi, pengikisan dan pergeseran. Sifat ini berhubungan dengan sifat ketahanan aus.

\section{Pengujian Kekerasan Menurut Rockwell}

Uji kekerasan Rockwell memperhitungkan kedalaman indentasi dalam keadaan beban konstan sebagai penentu nilai kekerasan. Sebelum pengukuran, specimen dibebani beban minor sebesar $10 \mathrm{~kg}$ untuk mengurangi kecenderungan ridging dan sinking akibat beban indentor. Sesudah beban minor diberikan, specimen langsung dikenakan beban mayor.

\section{E. Pengujian Kekerasan Menurut Vicker}

Uji kekerasan Vickers menggunakan penumbuk piramida intan yang dasarnya berbentuk bujur sangkar. Besarnya sudut antara permukaan-permukaan piramid yang saling 
berhadapan adalah $136^{\circ}$. Sudut ini dipilih, karena nilai tersebut mendekati sebagian besar nilai pebandingan yang diinginkan antara diameter lekukan dan diameter bola penumbuk pada uji kekerasan Brinell. Karena bentuk penumbuknya piramid, maka pengujian ini sering dinamakan uji kekerasan piramida intan.

\section{F. Pengujian Kekerasan Menurut Brinnel (HB)}

Uji kekerasan lekukan yang pertama kali banyak di gunakan serta disusun pembakuannya adalah metode yang di ajukan oleh J.A Brinell pada tahun1900. Uji kekerasan Brinell berupa pembentukan lekukan pada permukaan logam dengan memakai bola baja berdiameter $10 \mathrm{~mm}$ dan di beri beban $3000 \mathrm{~kg}$. Untuk logam lunak, beban di kurangi hingga tinggal $500 \mathrm{~kg}$, untuk menghindarkan jejak yang dalam, dan untuk bahan yang sangat keras, digunakan paduan kabrida tungsten, untuk memperkecil terjadinya distorsi identor. Beban diterapkan selama waktu tertentu, biasanya 30 detik, dan diameter lekukan diukur dengan mikroskop gaya rendah, setengah beban tersebut di hilangkan. Kemudian di cari harga ratarata dari 2 sampai 3 buah pengukuran diameter pada jejak yang berarah tegak lurus. Permukaan dimana lekukan akan dibuat harus relatif halus, bebas dari debu atau kerak.

\section{METODE PENELITIAN}

Penelitian ini dilakukan sejak tanggal 19 Mei sampai dengan 04 November 2015. Pengujian spesimen dilakukan di Laboratorium Mekanik jurusan Teknik Mesin Politeknik Negeri Ujung Pandang dan proses pembuatan spesimen dilakukan di bengkel PT. Baja Fabrikasi Indo Makassar.

\section{Persiapan Material Dasar.}

Persiapan material ini bertujuan untuk memastikan bahwa material yang digunakan dalam penelitian adalah plate baja JIS G3101 SS400. Sehingga sebelum pembuatan sampel, terlebih dahulu dilakukan pengujian tarik dan kekerasan untuk mengetahui sifat mekanis material tersebut.

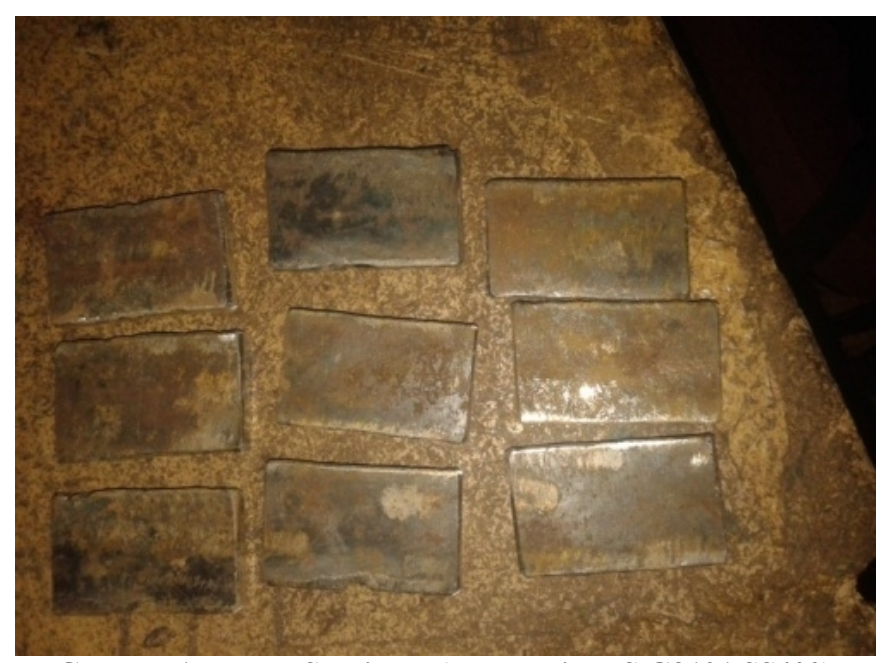

Gambar 1. Bahan Spesimen (Plate Baja JIS G3101 SS400)

Tabel 1. Komposisi kimia baja JIS G3101 SS400

\begin{tabular}{|l|l|}
\hline Carbon $(\mathrm{C})$ & $0.17-0.2 \%$ \\
\hline Silicon $(\mathrm{Si})$ & Dalam jumlah kecil \\
\hline Manganese $(\mathrm{Mn})$ & $1.4 \%$ \\
\hline Phosphorus $(\mathrm{P})$ & $0.045 \%$ \\
\hline Shulphur $(\mathrm{S})$ & $0.045 \%$ \\
\hline
\end{tabular}


29 Syaharuddin Rasyid, Tri Agus Susanto, Agung Setia Bela, M. Syukur Imam. Pengaruh Jenis Elektroda Dan Arus Las Pada Pengelasan Hardfacing Baja Jis 3101 Ss 400

2. Persiapan Elektroda.

Pada penelitian kali ini kami menggunakan 4 (empat) macam elektroda yaitu Elektroda DIN 8555 (E1-UM-350-GP), Elektroda AWS Class No. A5.13 (EFe2), Elektroda AWS Class No. A5.13 (EFe3) dan Elektroda AWS E7018.

3. Pembuatan Spesimen.

Bahan plat baja JIS G3101 SS400 tebal $6 \mathrm{~mm}$ dipotong dengan ukuran panjang $50 \mathrm{~mm}$ dan lebar $25 \mathrm{~mm}$, menggurinda sudut - sudut hasil potongan agar tidak tajam, menyiapkan peralatan pengelasan seperti travo las, topeng las, sarung tangan las, apron las dan lain - lain. Mengelas salah satu permukaan bahan dengan menggunakan elektoda AWS Class No. A5.13 (EFe3) dengan variasi arus pengelasan $(90 \mathrm{~A}, 115 \mathrm{~A}$ dan 140A) dan proses pendingin udara, mengelas salah satu permukaan bahan dengan menggunakan elektoda AWS Class No. A5.13 (EFe2) dengan variasi arus pengelasan $(90 \mathrm{~A}, 115 \mathrm{~A}$ dan 140A) dan proses pendingin udara, mengelas salah satu permukaan bahan dengan menggunakan elektoda DIN 8555 (E1-UM-350GP) dengan variasi arus pengelasan $(90 \mathrm{~A}, 115 \mathrm{~A}$ dan 140A) dan proses pendingin udara, mengelas salah satu permukaan bahan dengan menggunakan elektoda AWS 7018 dengan variasi arus pengelasan $(90 \mathrm{~A}, 115 \mathrm{~A}$ dan $140 \mathrm{~A})$ dan proses pendingin udara.

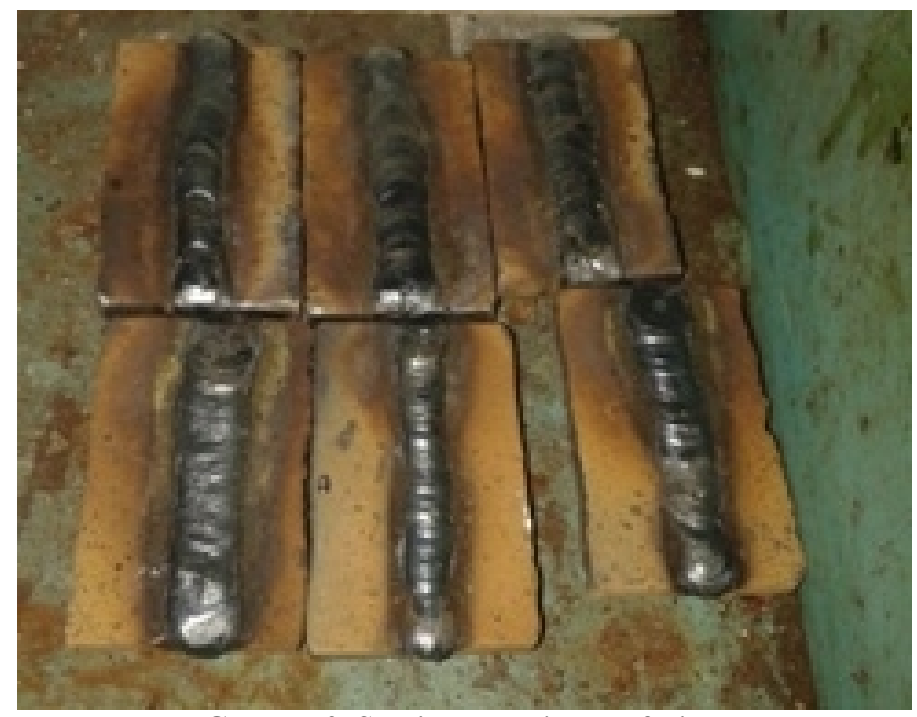

Gambar 2. Spesimen Hasil Hardfacing

4. Metode Pengambilan Data

Untuk memperoleh hasil yang lebih akurat metode pengambilan data dilakukan sebanyak masing-masing tiga kali pada tiga posisi yaitu kiri (awal pengelasan), tengah (tengah pengelasan) dan kanan (akhir pengelasan). Adapun ketiga posisi tersebut di tunjukkan pada gambar berikut ini. 


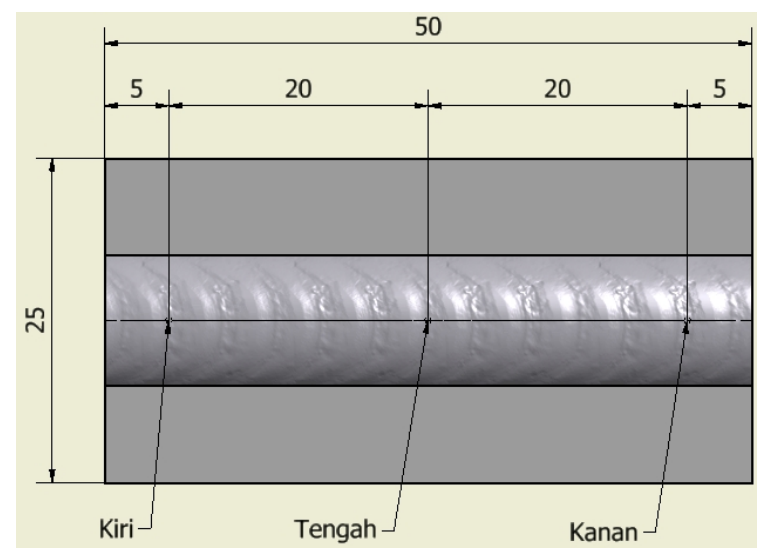

Gambar 3. Posisi Pengambilan Data

\section{Proses Pengujian Kekerasan}

Setelah spesimen uji telah selesai dibuat, langkah selanjutnya spesimen dilakukan pengujian kekerasan. Adapun langkah-langkahnya yaitu menyiapkan permukaan benda uji yang rata, menentukan metode pengujian kekerasan yang digunakan, menentukan besarnya beban dan ukuran penekan, memasang indentor pada dudukan, menghubungkan kabel power ke sumber listrik, menekan saklar ke posisi ON, mengatur metode pengujian yang digunakan melalui layar monitor mesin uji kekerasan, meletakkan spesimen pada landasan dengan kekencangan yang cukup, menekan spesimen hingga panah beban pada layar monitor terhubung, menunggu 5 detik hingga layar monitor menampilkan hasil pengujian, mencatat data hasil pengujian yang tampil pada monitor, setelah pengujian selesai, menekan tombol OFF pada sisi depan mesin uji kekerasan, menekan saklar ke posisi OFF pada sisi kiri mesin uji kekerasan, memutuskan kabel power dengan sumber listrik.

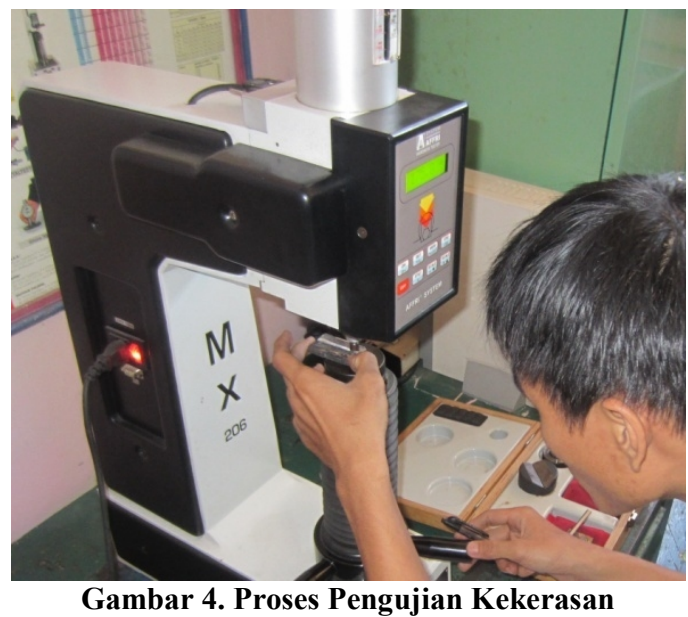

6. Metode Analisa Data

Pada saat melakukan uji kekerasan maka diperoleh data hasil pengujian. Data tersebut dianalisa secara statistik dengan metode analisis menggunakan software IBM SPSS Statistics 12 dan dengan metode deskriptif, dimana semua hasil analisis software IBM SPSS Statistics 12 yang diperoleh akan disajikan dalam bentuk tabel dan grafik. Berdasarkan tabel dan grafik tersebut hasil analisis akan deskripsikan dan diambil kesimpulan. 
31 Syaharuddin Rasyid, Tri Agus Susanto, Agung Setia Bela, M. Syukur Imam. Pengaruh Jenis Elektroda Dan Arus Las Pada Pengelasan Hardfacing Baja Jis 3101 Ss 400

\section{HASIL DAN PEMBAHASAN}

Berdasarkan jenis elektroda dan arus pengelasan pada pengelasan hardfacing baja JIS 3101 SS400 yang telah didesain sebelumnya maka diperoleh data-data nilai kekerasan seperti pada tabel 2 dibawah ini.

Tabel 2. Nilai Kekerasan Hardfacing Baja JIS 3101 SS400 Dengan Variasi Elektroda Terhadap Perubahan Arus Pengelasan

\begin{tabular}{|c|c|c|c|c|}
\hline No & Jenis Elektroda & $\begin{array}{c}\text { Arus Pengelasan } \\
\text { (Amperre) }\end{array}$ & Sampel & Nilai Kekerasan Rata-Rata (HRA) \\
\hline \multirow{9}{*}{1} & \multirow{9}{*}{ AWS Class No. A5.13 (Efe3) } & \multirow[t]{3}{*}{ I } & 1 & 80.73 \\
\hline & & & 2 & 80.93 \\
\hline & & & 3 & 80.67 \\
\hline & & \multirow{3}{*}{115} & 1 & 78.20 \\
\hline & & & 2 & 77.91 \\
\hline & & & 3 & 78.36 \\
\hline & & \multirow{3}{*}{140} & 1 & 70.20 \\
\hline & & & 2 & 70.91 \\
\hline & & & 3 & 70.29 \\
\hline \multirow{9}{*}{2} & \multirow{9}{*}{ AWS Class No. A5.13 (Efe2) } & \multirow{3}{*}{90} & 1 & 69.28 \\
\hline & & & 2 & 69.20 \\
\hline & & & 3 & 69.43 \\
\hline & & \multirow{3}{*}{115} & 1 & 66.59 \\
\hline & & & 2 & 66.83 \\
\hline & & & 3 & 66.83 \\
\hline & & \multirow{3}{*}{140} & 1 & 62.48 \\
\hline & & & 2 & 62.25 \\
\hline & & & 3 & 62.31 \\
\hline \multirow{9}{*}{3} & \multirow{9}{*}{ DIN 8555 (E1-UM-350-GP) } & \multirow{3}{*}{90} & 1 & 62.90 \\
\hline & & & 2 & 62.73 \\
\hline & & & 3 & 62.80 \\
\hline & & \multirow{3}{*}{115} & 1 & 61.75 \\
\hline & & & 2 & 61.53 \\
\hline & & & 3 & 61.83 \\
\hline & & \multirow{3}{*}{140} & 1 & 59.66 \\
\hline & & & 2 & 58.90 \\
\hline & & & 3 & 59.03 \\
\hline \multirow{9}{*}{4} & \multirow{9}{*}{ AWS E7018 } & \multirow{3}{*}{90} & 1 & 58.21 \\
\hline & & & 2 & 58.99 \\
\hline & & & 3 & 58.96 \\
\hline & & \multirow{3}{*}{115} & 1 & 55.50 \\
\hline & & & 2 & 56.05 \\
\hline & & & 3 & 56.61 \\
\hline & & \multirow{3}{*}{140} & 1 & 51.81 \\
\hline & & & 2 & 52.06 \\
\hline & & & 3 & 51.69 \\
\hline
\end{tabular}

Berdasarkan data-data nilai kekerasan yang terdapat pada Tabel 2, maka dibuatlah grafik hubungan antara nilai kekerasan dan jenis elektroda dengan variasi arus pengelasan sebagai berikut. 


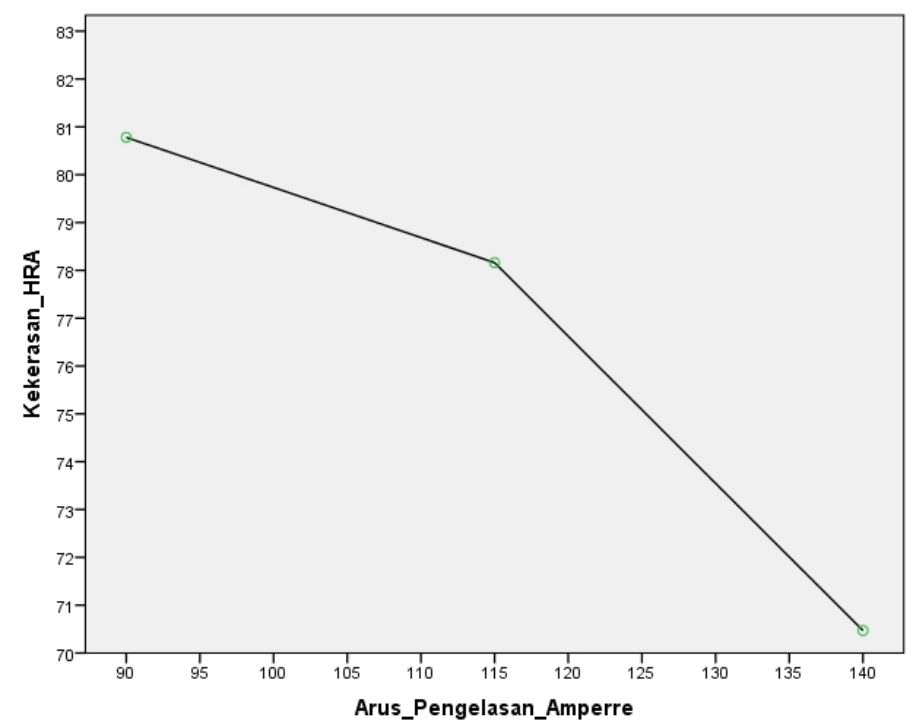

Gambar 5. Grafik Hubungan Antara Nilai Kekerasan dan Jenis Elektroda AWS Class No. A5.13 (EFe3) Dengan Variasi Arus engelasan.

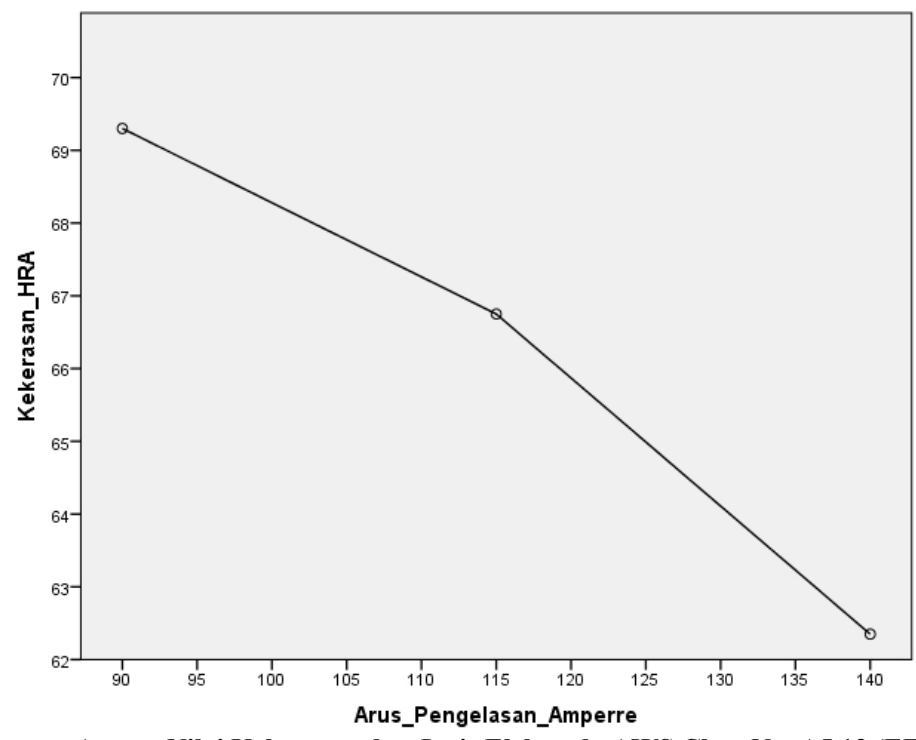

Gambar 6. Grafik Hubungan Antara Nilai Kekerasan dan Jenis Elektroda AWS Class No. A5.13 (EFe2) Dengan Variasi Arus Pengelasan 
33 Syaharuddin Rasyid, Tri Agus Susanto, Agung Setia Bela, M. Syukur Imam. Pengaruh Jenis Elektroda Dan Arus Las Pada Pengelasan Hardfacing Baja Jis 3101 Ss 400

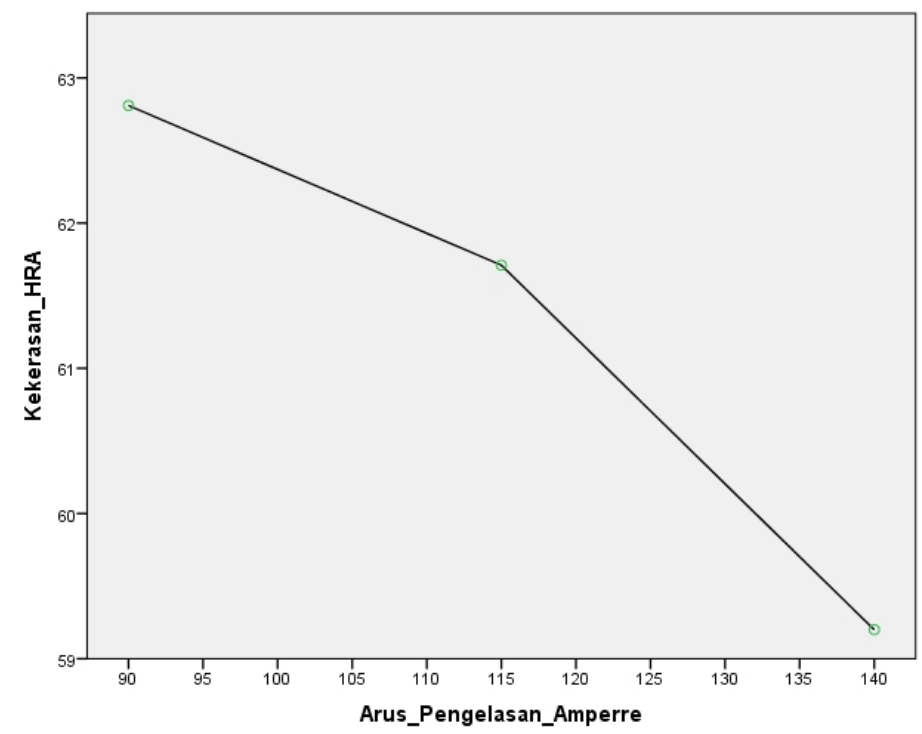

Gambar 7. Grafik Hubungan Antara Nilai Kekerasan dan Jenis Elektroda DIN 8555 (E1-UM-350-GP) Dengan Variasi Arus Pengelasan

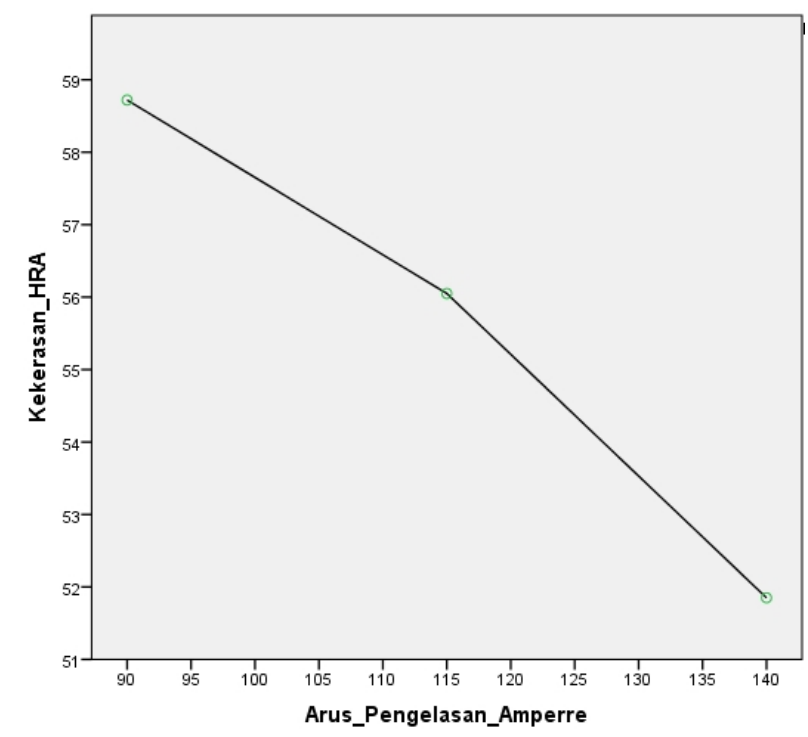

Gambar 8. Grafik Hubungan Antara Nilai Kekerasan dan Jenis Elektroda E7018 Dengan Variasi Arus Pengelasan 


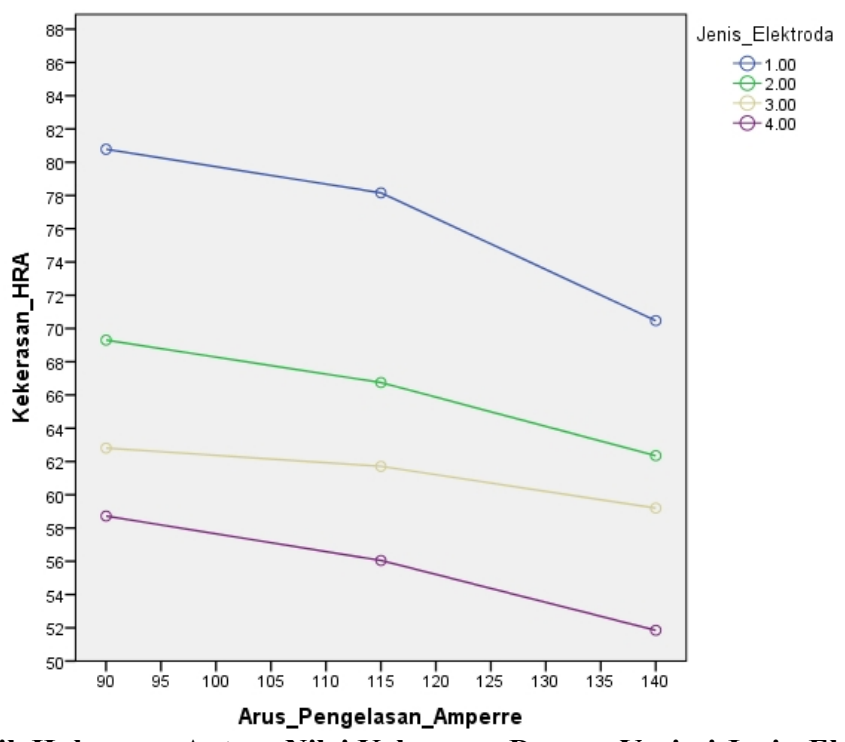

Gambar 9. Grafik Hubungan Antara Nilai Kekerasan Dengan Variasi Jenis Elektroda dan Variasi Arus Pengelasan

Keterangan:

\author{
Jenis_Elektroda 1.00 : AWS Class No. A5.13 (EFe3). \\ Jenis_Elektroda 2.00 : AWS Class No. A5.13 (EFe2). \\ Jenis_Elektroda 3.00 : DIN 8555 (E1-UM-350-GP). \\ Jenis_Elektroda 4.00 : AWS E7018.
}

Berdasarkan grafik-grafik di atas, terlihat bahwa pada semua jenis elektroda yang digunakan, semakin tinggi arus pengelasan yang digunakan, maka nilai kekerasan semakin mengalami penurunan. Hal ini terjadi karena pada arus pengelasan 90 Ampere maka temperatur pengelasan yang ditimbulkan lebih rendah dibandingkan pada arus pengelasan 115 Ampere dan 140 Ampere, sehingga struktur mikro yang terbentuk pada arus pengelasan 90 Amperre lebih banyak berbentuk Bainit, sedangkan struktur mikro yang terbentuk pada arus pengelasan 115 Amperre lebih banyak berbentuk Ferit Acicular dan struktur mikro yang terbentuk pada arus pengelasan 140 Amperre lebih banyak berbentuk Ferit Widstatten. Struktur mikro berbentuk Bainit, merupakan ferit yang tumbuh dari batas butir austenit dan terbentuk pada suhu $400-500^{\circ} \mathrm{C}$. Bainit mempunyai kekerasan yang lebih tinggi dibandingkan Ferit Acicular dan Ferit Widstatten, tetapi lebih rendah dibanding Martensit, karena Martensit akan terbentuk jika proses pengelasan dengan pendinginan sangat cepat dan struktur ini mempunyai sifat yang sangat keras dan getas sehingga ketangguhannya rendah.

Berdasarkan Gambar 9, nilai kekerasan yang paling tinggi yaitu pengelasan dengan menggunakan jenis elektroda 1.00 yaitu AWS Class No. A5.13 (EFe3), kemudian disusul dengan pengelasan dengan mengunakan jenis elektroda 2.00 yaitu AWS Class No. A5.13 (EFe2), kemudian pengelasan dengan mengunakan jenis elektroda 3.00 yaitu DIN 8555 (E1UM-350-GP) dan nilai kekerasan yang paling rendah yaitu pengelasan dengan menggunakan jenis elektroda AWS E7018.

\title{
IV. KESIMPULAN
}

Dari analisa hasil penelitian dan pembahasan yang telah diuraikan, maka dapat diambil beberapa kesimpulan sebagai berikut :

1. Hasil pengelasan hardfacing menggunakan elektroda AWS Class No. A5.13 (EFe3), AWS Class No. A5.13 (EFe2), DIN 8555 (E1-UM-350-GP), dan AWS E7018 menghasil kekerasan yang semakin menurun jika menggunakan arus pengelasan yang semakin besar. 
35 Syaharuddin Rasyid, Tri Agus Susanto, Agung Setia Bela, M. Syukur Imam. Pengaruh Jenis Elektroda Dan Arus Las Pada Pengelasan Hardfacing Baja Jis 3101 Ss 400

2. Parameter pengelasan yang paling dominan berpengaruh pada kekerasan permukaan adalah jenis elektroda (X1) dengan nilai 6.767 kemudian diikuti oleh parameter arus pengelasan (X2) dengan nilai 0.139 .

3. Nilai kekerasan tertinggi sampai terrendah dari hasil pengelasan hardfacing yaitu menggunakan elektroda AWS Class No. A5.13 (EFe3) nilainya kekerasannya yaitu 70.2 80.93 HRA, kemudian diikuti oleh elektroda AWS Class No. A5.13 (EFe2) nilainya kekerasannya yaitu 62.25 - 69.43 HRA, kemudian elektroda DIN 8555 (E1-UM-350-GP) nilainya kekerasannya yaitu 58.90 - 62.90 HRA dan nilai kekerasan yang terrendah yaitu pengelasan dengan menggunakan elektroda AWS E7018 nilainya kekerasannya yaitu 51.69 58.99 HRA, sehingga elektroda AWS E7018 tidak disarankan untuk digunakan sebagai elektroda Hardfacing.

\section{DAFTAR PUSTAKA.}

Algifari. 2000. Analisis Regresi, Teori, Kasus \& Solusi. BPFE UGM, Yogyakarta.

Dahlan, Hadijaya.2000.Pengaruh Variasi Beban Indentor Micro Hardness Tester Terhadap Akurasi Data Uji Kekerasan Material.Dalam Jurnal Ilmiah Urania, VI (23-24): 5762.

Nugroho, Kristianto Suro. 2010.Analisa Pengujian Kekerasan Material Baja Karbon Rendah, Besi, Tembaga, Aluminium Serta Zn (Seng) Dengan Menggunakan Metode Uji Kekerasan Brinell. Proposal Tugas Akhir. Tangerang Selatan: Universitas Pamulang.

Pradeep, G.R.C. DKK. 2012. Comparative Study of Hardfacing of AISI 1020 Steel by Gas Welding and Tig Welding Process. Dalam Jurnal Ilmiah IOSR Journal of Enginering (IOSRJEN), II (9): 18-22.

Pranata, Abdi. 2011. Hardness Test. Laporan Resmi. Surabaya: Institut Teknologi Sepuluh Nopember.

Nur, Rusdi, and Muhammad Arsyad Suyuti. Pengantar Sistem Manufaktur. Deepublish, 2017.

Santoso, Joko.2006.Pengaruh Arus Pengelasan Terhadap Kekuatan Tarik dan Ketangguhan Las SMAW Dengan Elaktroda E7018.Skripsi.Semarang: Universitas Negeri Semarang.

Singh, Harvinder. 2014. Studies the Effect of Iron Based Hardfacing Electrodes on Stainless Steel Properties Using Shielded Metal Arc Welding Process. Dalam Jurnal Ilmiah International Jurnal of Research in Advent Technolog, II (4): 419-430.

Sonawan, H. 2004. Pengantar Untuk Memahami Pengelasan Logam. Bandung: Alfa Beta.

Sudjana. 2002. Metode Statistika. Bandung: Tarsito.

Steelindo Persada. 2015. SS400 Bukan Stainless Steel Tapi Structural Steel.http://www.steelindopersada.com/2015/03/ss400-bukan-stainless-steeltapi.html. Diakses Pada 31Mei 2015.

Sunandar, Arif Fisca. 2012. Perbedaan Karakteristik Hasil Pengelasan Metode GTAW dan SMAW Terhadap Baja Tahan Karat 316L. Skripsi. Depok: Universitas Indonesia.

Surdia, Tata. 1999. Pengetahuan Bahan Teknik. Jakarta: Pradnya Paramita.

Trihendradi, Cornelius. 2004. Langkah Mudah Memecahkan Kasus Statistik: Deskriptif, Parametik, dan Non-Parametik dengan SPSS 12. Yogyakarta: Andi.

Waluyo, Joko DKK. 2012. Optimalisasi Pemanfaatan Baja Konstruksi Dan Kikir Bekas Sebagai Pahat Bubut. Dalam Jurnal Ilmiah Jurnal Teknologi, V (1): 1-8.

Wiryosumarto, Harsono. 2000. Teknologi Pengelasan Logam. Jakarta: Pradnya Paramita. 